\title{
RULES OF DECISION IN NONDIVERSITY SUITS
}

Despite Erie R.R. v. Tompkins' famous statement that "there is no federal general common law," 1 judge-made law ungoverned by constitutional or statutory provisions - common law-has emanated from the courts of the United States since their inception. ${ }^{2}$ The very day the Supreme Court decided Lric it resolved another case by resort to rules of "federal common law."' Such rules are still frequently applied outside of the single area of diversity jurisdiction in which Erie bound federal judges to follow state common law." Under other heads of civil jurisdiction, ${ }^{5}$ however, the line of demarcation between state and federal common law remains unclear. Criteria for selecting one or the other as a rule of decision ${ }^{6}$ are inadequately defined. Federal

1. 304 U.S. 64,78 (1938).

2. The term "common law" as used throughout this Comment refers to the unwritten decisional law formulated by the courts and based upon their decisions, not the gencral body of legal principles known as "the Common Law" which distinguishes our legal system from the civil law nations. See 1 Beale, Conflict or Laws 26-28 (1935).

It was recognized that federal courts, in construing the federal constitution and statutes, were evolving a true federal common law dependent upon national authority, as opposed to federal interpretation of the common law of the states. Smith v. Alabama, 124 U.S. 405, 478-79 (1888); see 1 Moore, Federal. Practice If 0.318[1] (1959).

3. Hinderlider v. La Plata River \& Cherry Creek: Ditch Co., 304 U.S. 92 (1938).

4. See Note, Exceptions to Erie v. Tompkins: The Survival of Federal Common Land, 59 Harv. L. Rev. 966 (1946); Comment, 40 Cornell L.Q. 561, 563-65 (1955); Note, 34 CORNELL L.Q. 110 (1948).

5. The judicial power of the United States, derived from the U.S. Const. art. 111, $\$ 2$, embraces two general categories of litigation. Jurisdiction is sometimes based on the nature of the subject matter-suits arising under the federal constitution, laws, and treaties, and cases of admiralty and maritime jurisdiction. Jurisdiction also rests on the nature of the litigants-cases affecting ambassadors, consuls and public ministers, controversies to which the United States is a party, controversies between two or morc states, between a state and citizens of another state, between citizens of different states, and between a state or its citizens and a foreign state or its citizens. A further heid of jurisdiction, suits between citizens of the same state claiming lands under grants of different states, combines both party and subject matter characteristics. In addition to the article III courts, there are other federal courts whose authority derives from the legisiative power granted Congress under articles I and IV. These tribunals now include the territorial courts, see 1 Moore, Federal Practice \o 0.3[3.-1] (1959), and probably the Court of Customs and Patent Appeals, the Customs Courts and the Court of Claims, id. at $\{0.4[3]$. Article I also authorizes federal jurisdiction excrcised by military courts, although these are held technically to be outside the regular jutlicial system. Id. at $\Uparrow 0.5[1]$; Dynes v. Hoover, 61 U.S. (20 How.) 65, 79 (1857). But cven in the nonarticle III courts, established to adjudicate matters primarily federal in character, the question of applicability of state law arises. See, e.g., United States v. Woolridge, 10 U.S.C.M.A. 510, 514 n.4 (1959); Rhode Island Discount Co. v. United States, 118 Ct. Cl. 262, 94 F. Supp. 669 (1951).

6. By "rules of decision" are meant the laws which are applied by courts to determine the questions brought before them. This Comment is concerned only with suits brought in federal courts, although the state courts have a significant role in enforcing federally- 
courts often apply state law without indicating whether their selection is mandatory or discretionary. ${ }^{7}$ If discretionary, the reasons for exercising the option are not satisfactorily explained. On the other hand, when the statc rule is rejected in favor of "federal law," the courts do not always specify whether they are making common law in the usual sense, or only implementing a particular statutory policy. Nor do they detail the method and hierarchy of authority through which federal common law is derived.8

This Comment will focus primarily upon the two areas of federal jurisdiction where the problem is currently the most significant, suits to which the United States is a party and those which involve interpretation of a federal statute. The expanding role of the United States as a litigator ${ }^{8}$ and the widening range of federal legislation ${ }^{10}$ make these areas quantitatively of great importance, while qualitatively they now present greater difficulties than fields such as bankruptcy and admiralty, where the problem has alrady been extensively discussed.11 The Comment will first describe the constitutional and statutory bases for the choice of rules of decision in the federal courts. This will lay the groundwork for a critique of the wide range of unfettered judicial choice between federal and state law now prevailing in nondiversity suits. Finally, the Comment will propose a method of analyzing the rules-of-decision problem, attempting to identify those considerations which ought to govern decisions in this area.

\section{HISTORICAL BACKgROUND}

The records of the Constitutional Convention do not reveal any discussion of the rules of decision to be applied in federal courts. ${ }^{12}$ The reports of the

created rights. See Hart, The Relations Between State and Federal Lan, 54 Cinsus. L. REV. 489, 498 (1954).

7. See, e.g., Schuman Co. v. Nelson, 219 F.2d 627 (3rd Cir. 1955); latliff liad Co. v. Cox, 142 F.2d 876 (6th Cir. 1944); United States v. Hansett, 120 F.2d 121 12d Cir. 1941); United States v. Schumacher, 154 F. Supp. 425 (E.D. IVis. 1957) : Laulisik. \& Trading Corp. v. RFC, 147 F. Supp. 193 (S.D.N.Y. 1956).

8. For an example of the freewheeling use of precedent in the formulation wi "icderal law," see CCC v. Rosenberg Bros. \& Co., 243 F.2d 504 (9th Cir. 1957), citing iuur Supreme Court cases, three Sixth Circuit cases, an Eighth Circuit case, a Second (ircuit case, a district case from the District of Mfaryland, state cases from Ohio, Cunnecticut, and Illinois, Williston on Sales, the Uniform Sales Act, and one Latin maxim.

9. For the fiscal year ending June 30,1957, 895 civil cases were commenced in the circuit courts, Adarinistrative Office of the U.S. Courts Ansr. Rep. 160 (1457). and 19,914 in the district courts, id. at 170 . In 1935, about 10,500 such cases wire hiled in the district courts. Adarinistrative OfFice of the U.S. Courts Axs. Res. chart 3 (1942).

10. See Miller, The Constitutional Law of the "Sectrity State," 10 Stan. L. Ran. 620, 626-28 (1958).

11. See, e.g., Gilarore \& Black, Adartralty $374-86$ (1957) ; Hill, The Eric Doctrime in Bankrupicy, 66 HaRv. L. Rev. 1013, 1016-19 (1953).

12. There was considerable controversy over the existence and jurisdiction of iederal courts. See, e.g., 1 Farrand, The Records of the Federal Conventio: of $1787,22$. 
ratification debates are but slightly more helpful. The only express discussion of the point seems to be John Marshall's reply to a Virginia delegate who had asked what law would govern in diversity cases. Taking the example of contract suits, Marshall stated that the usual conflicts rule, applying the law of the state in which the contract was made, would be adhered to by the federal conrts. ${ }^{13}$ The implication is that these courts were not to have power to formulate independent federal rules of decision in divensity cases. ${ }^{14}$ On the other hand, distinct and independent federal rules were apparently contemplated for several of the nondiversity heads of jurisdiction. For three of these-admiralty, suits arising under treaties, and cases affecting ambassadors-the need for a uniform rule was stressed by ratification speakers. ${ }^{15}$ There is also the suggestion that in suits between a citizen and an alien, federal courts would not be bound by "partial and wicked" state laws. ${ }^{16}$ The grant of federal jurisdiction over suits between states, based on the theory that state courts were incompetent to decide

$220,231,232,243,244,292$ (rev. ed. 1937) [hereinafter cited as FARRAND] ; 2 id. 45-46, 132, 157,$172 ; 3$ id. 117.

The only proceedings in the Federal Convention bearing even remotely on the rules of decision problem, 1 id. 2-23, 238; 2 id. 45-46, 132-33, 136, 146-47, evidence a concern over whether state courts would fairly adjudicate federal matters.

The earlier drafts of article III, less specific than that finally adopted, show an intention to give the federal courts jurisdiction over cases involving "the national peace and harmony," admiralty, impeachment of national officers, and collection of national revenuc. See 1 id. 22, 223-24, 231, 238, 244; 2 id. 157; 172-73, 186, 600. But they also contain no suggestion as to the applicable rules of decision.

13. 3 Elliot, Debates on the Federal Constitution 556-57 (2d ed. 1836) [hereinafter cited as Elutot].

14. In other state ratifying conventions, however, there were comments sounding very much like the doctrine of Swift v. Tyson, 41 U.S. (16 Pet.) 1 (1842). See 2 ELL1or 491 ("I would ask how a merchant must feel to have his property lie at the mercy of the laws of Rhode Island") (Wilson) ; $3 i d$. at 535,$549 ; 3$ id. at 565 ("a droll sight, to see a man on one side of the street punished for a breach of federal law, and on the other side another man rewarded by the state legislature for the same act") (Grayson) ; 3 id. at 566 ("Whether.... [the federal courts] will make a law other than the state laws, 1 cannot determine") (Grayson). But these statements can be interpreted as meaning that the federal courts can select the law of the proper state, not that they are free to form their own body of substantive law.

On the whole, the federal judiciary seems to have been conceived of as providing impartial tribunals, against the fear of prejudiced state courts. See, e.g., 3 ElL1or 533; 3 id. at 535 (local prejudices). See also The Federalist No. 80, at 587, 591 (Hamilton ed. 1871) (Hamilton).

15. These [treaties] may involve us in controversies with foreign nations. It is necessary, therefore, that they should be determined in the courts of general government. ... If, in any case, uniformity be necessary, it must be in the exposition of treaties. ... The same principles hold with respect to cases affecting ambassadors and foreign ministers. To the same principles may also be referred their cognizance in admiralty and maritime cases.

3 Ellior 532 (Madison); accord, 2 Ellior 489-90; 3 Ellior 570-71. See also TuE Federalist No. 80, at 587, 588-89, 593 (Hamilton ed. 1871) (Hamilton).

16. 2 Ellior 492-93. 
such controversies, seemed to recognize another area in which federal rules of decision would be applicable.17 Similarly, state rules were considered inapposite in the cases of conflicting land grants, since each court would be bound by its own executive's or legislature's grant. ${ }^{18}$ For the two other heads of federal jurisdiction-cases arising under the constitution, laws, and treaties of the United States and cases in which the United States is a party-even this scant guidance is unavailable. ${ }^{10}$

Whatever their reticence on the subject at the Convention, many of the Framers participated in the First Congress' adoption of the Rules of Decisiun Act, section 34 of the Judiciary Act of 1789 . This provision, still in effect, stipulated that

the laws of the several states, except where the constitution, treaties, or statutes of the United States shall otherwise require or provide, shall be regarded as rules of decision in trials at common law in the courts of the United States in cases where they apply.20

The act is not, as is sometimes thought, confined to diversity cases; "trials at common law" has long been construed to embrace the other bases of federal jurisdiction. ${ }^{21}$ Under some of these nondiversity heads of jurisdiction, however, the question of state or federal decisional rules has been resolved in favor of federal judge-made law almost without reference to the Rules of Decision Act. Thus, in cases involving ambassadors and consuls, the status of the foreign representative is a matter of federal law. ${ }^{22}$ Suits under the conflicting land

17. See 2 id. $490-91 ; 3$ id. 530, 571, 591.

18. 2 id. $481 ; 3$ id. 523 ; see also The Federalist No. 80 , at 587, 589-90, 591, 593 (Hamilton ed. 1871) (Hamilton).

19. Reasons given for federal jurisdiction over suits to which the United States is a party are discussed at note 110 infra and accompanying text.

20. Judiciary Act of 1789 , ch. $20, \S 34,1$ Stat. 92 . The section now uses the term "civil actions" instead of "trials at common law." 28 U.S.C. § 1652 (1958). [The Rules of Decision Act is hereinafter referred to in the footnotes as Section 34.]

Section 34 was held to be merely declarative of the rule which would have existed in the absence of statute, and therefore did not by implication exclude the use of state rules of decision in federal equity suits. Mason v. United States, 260 U.S. 545, 558-54 (1923) ; see Dawson v. Kentucky Distilleries \& Warehouse Co., 255 U.S. 288 (1921): Missouri, Kan. \& Tex. Trust Co. v. Krumseig, 172 U.S. 351 (1S99); Jackson v. Ludeling, 99 U.S. 513 (1878) (applying civil law); Brine v. Insurance Co., 96 U.S. 627 (1877).

21. See, e.g., Chattanooga Foundry \& Pipe Works v. City of Atlanta, 203 U.S. 390 (1906) (Sherman Act treble damage suit); Campbell v. Haverhill, 155 U.S. 610 (1895) (patent infringement); Andreae v. Redfield, 98 U.S. 225 (1878) (suit to recover customs duties illegally exacted); United States v. Klein, 153 F.2d 55 (8th Cir. 1946) (United States a party); Quinette v. Bisso, 136 Fed. 825 (5th Cir.), cert. denicd, 199 U.S. 60 u (1905) (state law applied in suit in admiralty; Section 34 not mentioned) ; 1 Mooss. Fat ERAL Practice If 0.305[3] (1959).

22. Ambassadors and public ministers are immune to suit, 1 Stat. 117 (1790), 22 U.S.C. § 252 (1958); exclusive jurisdiction of suits against consuls and vice consuls is given to the district courts, 28 U.S.C. $\$ 1351$ (1958). Consuls are clothed with diplomatic immunity for acts in behalf of their government. Jones v. Le Tombe, 3 U.S. (3 Dall.) 
grants head are now rare but the older case law established that federal rules of decision should be shaped..$^{23}$ In suits between states, the propriety and necessity of federal decisional rules has consistently been recognized. ${ }^{24}$ The essentially federal character of admiralty and maritime decisional law has likewise been dear, although the "saving-to-suitors" clause has given rise to a complex interaction of state and federal law. ${ }^{25}$

Under other grants of federal jurisdiction, judicial interpretation of the Rules of Decision Act has played a more important, and changing role. Although the act is drafted in terms which indicate a presumption in favor of applying state rules of decision, three phrases might be construed to restrict the scope of state law and to present an opportunity for creating a federal common law. "The phrase directing use of state rules of decision only "in cases where they apply," seems never to have been expressly relied on for this purpose. ${ }^{20}$ The Supreme Court has suggested, however, that this limitation would relieve federal courts from the necessity of following state laws which discriminate against the federal government, ${ }^{2 \pi}$ and, generally, state laws which are inapposite due to the nature of a suit, e.g., a suit between states. ${ }^{28}$ The second phase, confining state rules of de-

384 (1798). Status is determined by federal law. See Lyders v. Lund, 32 F.2d 308 (N.1). Cal. 1929); Landley v. Republic of Panama, 31 F. Supp. 230 (S.D.N.Y. 1940).

The acts of consuls as private citizens may be sued upon, and apparently state law governs. See Carl Byoir \& Associates, Inc. v. Tsune-chi Yu, 112 F.2d 885 (2d Cir. 1940). But cf. Rotrschaefer, Constitutional Law $\$ 222$, at 435 (1939). Federal courts will take no cognizance of marital relations, leaving this matter to the states. Ohio $c . r \mathrm{rcl}$. Popovici v. Agler, 280 U.S. 379 (1930). And the status of a foreign minister passing through the United States has been determined by state law. Bergman v. De Sicyes, 170 F.2d 360 (2d Cir. 1948). But sce Note, 33 MrNo. L. Rev. 540 (1949) (criticizing Di' Sieyes.)

Only three cases have been found involving the Supreme Court's original jurisdiction. Jones v. Le Tombe, 3 U.S. ( 3 Dall.) 383 (1798) (court dismissed suit against French consul acting in behalf of his government); Casey v. Galli, 94 U.S. 674 (1876) (vice consul's liability as stockholder of national banking association decided on merits: 110 discussion of jurisdictional question); ex parte Gruber, 269 U.S. 302 (1925) (article III, $\$ 2$ held inapplicable to suits against American consul).

23. See Colson v. Lewis, 15 U.S. (2 Wheat.) 377 (1817) ; Town of Pawlet v. Clart: 13 U.S. (9 Cranch) 291, 324 (1815) ("We will now consider, what is the legal operation of such a grant, at the common law ; and how far it is affected by the laws of New Humpshire or Vermont.").

24. "No man ought certainly to be a judge in his own cause .... This principle hats no inconsiderable weight in designating the federal courts, as the propert tribunals for the determination of controversies between different states . . ." THE FEDERALIST No. 80, at 591 (Hamilton ed. 1864) (Hamilton); see New Jersey v. New York, 283 U.S. 336, 342-43 (1931) ; Connecticut v. Massachusetts, 282 U.S. 660, 670-71 (1931); Arkansas v. Tennessee, 246 U.S. 158, 175-76 (1918); Kansas v. Colorado, 206 U.S. 46, 95 (1907).

25. Gilmore \& Black, Admiralty 33-36, $374-86$ (1957).

26. The only extensive discussion that has been found is in Campbell v. Haverhill, 155 U.S. 610, 614-16 (1895).

27. Ibid.; cf. Puhfahl v. Estate of Parks, 299 U.S. 217 (1936); Metcalf v. Watcrtown, 153 U.S. 671 (1894) ; Cooke v. Avery, 147 U.S. 375 (1893); Massingill v. Downs, 48 U.S. (7 How.) 760 (1849).

28. Campbell v. Haverhill, 155 U.S. 610, 614-16 (1895). 
cision to controversies in which the federal constitution, treaties, or statutes did not "otherwise require or provide," was also construed narrowly by the early. federal courts. If the state law in question was not inconsistent with the federal statute, the silence of Congress was taken to mean that state law was to be followed. ${ }^{29}$ Similarly, the earlier courts seemed less willing than recent courts to find state law superseded when Congress had legislated in areas within its exclusive control. ${ }^{30}$ And even when federal law was clearly applicable, state law was accorded great weight as a matter of comity. ${ }^{31}$

By interpreting the third phrase- "the laws of the several states"-to refer only to state statutes and "local" common-law rules, however, the famous decision in Swift $v$. Tyson ${ }^{32}$ in 1842 circumscribed the presumption in favor of state law and furnished federal judges with a significant opportunity to creatc common law. Mr. Justice Story reasoned that the act did not "apply . . . to questions of a ... general nature, not at all dependent upon local statutes or local usages of a fixed and permanent operation."33 The Swift interpretation of the act remained in force until Erie R.R. v. Tompkins in 1938. Erie declared that "the laws of the several states" embraced both statute and decisional law, thus removing Swift's restriction on the act's general applicability, and making state common law the rule of decision in diversity suits. ${ }^{30}$ Since Eric, statc common law seems also to afford the rule of decision in suits between states and citizens of another state, ${ }^{37}$ and in alienage cases. ${ }^{38}$

29. Chattanooga Foundry \& Pipe Works v. City of Atlanta, sipro note 21, at 397; Campbell v. Haverhill, supra note 21; Metcalf v. Watertown, supra note 27; Barney v. Oelrichs, 138 U.S. 529 (1891) (Section 34 not discussed); Andreae v. Redfield, supra note 21 , at 235 .

30. See Savage v. Jones, 225 U.S. 501 (1912); Reid v. Colorado, 187 U.S. 137 (1902) ; Missouri, Kan. \& Tex. Ry. v. Haber, 169 U.S. 613 (1898); Smith v. Alabama, 124 U.S. 465 (1888); Sherlock v. Alling, 93 U.S. 99 (1876). Compare Pennsylvania v. Nelson, 350 U.S. 497 (1956) ; New York Cent. R.R. v. Winfield, 244 U.S. 147 (1917). See also Biklé, The Silence of Congress, 41 HARv. L. Rev. 200 (1927).

31. See, e.g., Green v. Lessee of Neal, 31 U.S. (6 Pet.) 291, 298 (1832) ; Jackson cx dem. St. John v. Chew, 25 U.S. (12 Wheat.) 153, 167 (1827) ; Daly's Lessee v. James, 21 L'.S. (8 Wheat.) 495, 535 (1823) ; United States v. Wonson, 28 Fed. Cas. 745, 749 (No. 16750 )

(C.C.D. MIass. 1812).

32. 41 U.S. (16 Pet.) 1 (1842).

33. Id. at 18-19.

34. 304 U.S. 64 (1938).

35. Id. at 78 .

36. Id. at $72-73$.

37. Such suits per se do not present a federal question. See, e.g., Pennsylvania $v$ : Wheeling \& Belmont Bridge Co., 54 U.S. (13 How.) 518, 560-61, 589-90 (1851): Plaquemines Tropical Fruit Co. v. Henderson, 170 U.S. 511, 520 (1898). Of course, such suits can involve questions of a federal nature. See Georgia v. Pennsylvania R.R., 324 U.S. 439 (1945).

Federal jurisdiction over such suits is now vested originally, but not exclusively, in the Supreme Court. 28 U.S.C. \$ 1251 (b) (3) (1958). Thus a state may bring suit against citizens of another state in her own courts. Plaquemines Tropical Fruit Co. v. Henderson, supra. See generally Moore, The U.S. Judicial Code $\{0.03(54)$, at $627-30$ (1949).

38. Diversity and alienage are now treated as one in the Judicial Code 28 U.S.C. \$ 1332 (1958); see MoORe, The U.S. Junicial Code 【 0.03(45), at 309 (1949). 
If applied to other jurisdictional areas, the broader implications of Eric-the statement that there is no federal general common law-might have further confined the making of federal law under the "otherwise require or provide" clause of the Rules of Decision Act. But in a series of cases decided soon after Erie, the Court began to make clear that Erie was not so to be extended; to the contrary, the "otherwise require or provide" clause seemed to permit a greater intrusion of federal decisional rules in cases involving federal statutes or the United States as a litigant. ${ }^{39}$ Board of County Comm'rs v. United States, ${ }^{40}$ decided in 1939, held Erie's choice of law rule inapplicable to a suit brought by the United States as guardian of an Indian illegally taxed by Missouri. The government claimed interest on the refunded tax payments despite a state law refusing to pay interest. The Court decided that since the tax-exemption right was derived from a federal treaty, state rules were not binding; it chose to respect them, however, because of congressional silence and because the Government had misled the state tax officers. The following year, in Dictrick " Greaney, ${ }^{41}$ a national bank receiver brought suit on a note executed to circumvent a provision of the National Bank Act; the maker clefended on the theory that state common law voided notes given in illegal transactions. The Court held that the policy of the act precluded the defense notwithstanding Erie. In 1941, in Royal Indem. Co. v. United States, ${ }^{42}$ the Court reviewed a ruling that New York law required defendant surety company to pay 6 per cent interest on the statutory tax obligation owed by its principal to the United States. ${ }^{43}$ The Supreme Court, although affirming the propriety of the 6 per cent charge, expressly held state law not binding in the case of contracts with the federal government. The following year, D'Oench, Duhme \& Co. v. FDIC 4 raised the question of whether the maker of an accommodation note executed before the passage of the Federal Reserve Aot of 1934 conld raise the state common-law defense of no consideration in a suit brought under that act by the FDIC. The Court held that the policy of the Federal Reserve Act forbade the assertion of the defense. And in 1943 Clearfield Trust Co.v. United Stales tit applied a federal common-law rule of negotiable instruments, contrary to the state rule, primarily because the negotiable instrument had been created by the exercise of the Government's constitutional authority.

\section{The Decision to Apply Federal Law}

When courts announce that federal law will apply as a rule of clecision, the term "federal law" can have many meanings. ${ }^{40}$ The only meaning common

39. See Note, 53 Colurr. L. Rev. 991, 1007-08 (1953); Note, 59 Harv. L. Rev. 906 (1946).

40. 308 U.S. 343 (1939).

41. 309 U.S. 190 (1940).

42. 313 U.S. 289 (1941).

43. United States v. Royal Indem. Co., 116 F2d 247 (2d Cir. 1940).

44. 315 U.S. 447 (1942).

45. 318 U.S. 363 (1943).

46. See generally Mishkin, The Variousness of "Federal Law": Competence and Dis- 
to all uses is the fact that the federal court is not bound to apply the state rule. The considerations which lead a federal court to this decision will vary according to the nature of the case before it. For example, the reasons for which a court does not follow state law in a suit between states are not the same reasons which lead it to reject state law when admiralty jurisdiction is involved. ${ }^{47}$ Thus there can be no single formula which will govern the choice of decisional rules in every case. Moreover, the fact that federal law is chosen for different reasons in each case will affect the courts formulation of a substantive "federal" rule. There is no complete and interchangeable body of "federal law" which can be inserted mechanically into the place of the rejected state rule. The federal court may look to the body of federal common law developed under Swift, ${ }^{48}$ to the law of other states, ${ }^{10}$ to principles of international law, ${ }^{50}$ or to policies expressed by Congress; $;^{51}$ sometimes the courts decide that the state law in question is the best rule even though the federal court is not bound to accept it.52 The different contexts in which "federal law" has been used reveal the many different functions described by that term.

One type of "federal law" is the decisional rules used to resolve disputes between two states. Clearly the federal judge cannot be bound by the rules which one of the rival claimants has established, so that a "federal law" of interstate controversies has evolved. The substance of this "federal law," consistent with its origins, has reflected principles of international law and a policy of arbitration by a neutral third party. ${ }^{\text {t3 }}$ Such law is also expounded and applied in suits between private parties. Thus in Hinderlider v. La Plata River \& Cherry Creek Ditch Co., ${ }^{54}$ the Supreme Court reviewed a state court decision on interstate division of water rights because the suit involved a question of "federal common law." Where private parties claim under conflicting grants from different states, the same considerations indicate that state law should not govern the controversy..$^{\text {s5 }}$

cretion in the Choice of National and State Rules for Decision, 105 U. PA. L. REv. 797 (1957) ; Note, 53 Colum. L. Rer. 991, 1002-06 (1953).

47. Compare text accompanying notes 53-55 infra, with text accompanying nutes 61-62 infra.

48. E.g., Clearfield Trust Co. v. United States, 318 U.S. 363 (1943), discussed in text accompanying notes 83-91 infra.

49. E.g., Darlington, Inc. v. FHA, 142 F. Supp. 341 (E.D.S.C. 1956), rev'd on other grounds, 352 U.S. 977 (1957).

50. E.g., Kansas v. Colorado, 185 U.S. 125 (1902). In addition, the court may lool: to principles of English common law. Mfoore v. United States, 91 U.S. 270, 273 (1876).

51. E.g., D'Oench, Duhme \& Co. v. FDIC, 315 U.S. 447 (1942), discussed in text accompanying note 44 supra.

52. E.g., Royal Indem. Co. v. United States, 313 U.S. 289 (1941), discussed in text accompanying notes $42-43$ supra.

53. See cases cited note 24 sipra.

54. 304 U.S. $92(1938)$.

55. See Smoot Sand \& Gravel Corp., v. Washington Airport, Inc, 223 U.S. 348 (1931); Moore v. MicGuire, 205 U.S. 214 (1907); St. Louis v. Rutz, 138 U.S. 226, (1891); Coffee v. Groover, 123 U.S. 1 (1887); Howard v. Ingersoll, 54 U.S. (13 How.) 
Another type of "federal law" is that applied in cases involving the sovereign relations of the United States with other nations. From the drafting of the Constitution, authorities have accepted the view that in this area state law has no relevance. ${ }^{56}$ The Framers felt that in dealings with foreign nations, there must be one uniform law, and that an individual state could not be allowed to embarrass or jeopardize the international relations of the United States. 57 Thus the interpretation of a treaty depends on "federal law." In cases involving ambassadors, consuls, and foreign ministers, the status of the officer or the capacity in which he acted presents a federal question, which if decided in his favor bars an action against him for any state or federal claim..$^{59}$

Admiralty and bankruptcy courts also formulate "federal law." From the grant to Congress of the power to establish uniform rules of bankruptcy, the courts have implied a duty to fill in the interstices of uniform legislation with uniform judge-made law drawn from the policies of the Bankruptcy $\Lambda$ ct. ${ }^{\prime \prime \prime}$ The constitutional grant of admiralty jurisdiction has been held to imply both congressional and judicial power to establish rules of federal substantive law in this area. ${ }^{61}$ The Supreme Court has described the principles used uncler the Jones Act as "a seasoned body of maritime law developed by the experience of American courts long accustomed to dealing with admiralty in reconciling our own with foreign interests and in accommodating the reach of our own laws to those of other maritime nations." 62

"Federal law" also governs the interpretation and application of the fecleral constitution and statutes. Just as a state court's construction of its own conlu stitution and statutes is binding upon federal tribunals, ${ }^{03}$ so the federal court? are the final judicial authority on the meaning of the federal constitution and statutes. ${ }^{64}$ Here the proper role of the courts is the interpretation and im plementation of national legislative direotions, and state law often has no rele

380 (1851) ; Poole v. Lessee of Fleeger, 36 U.S. (11 Pet.) 185 (1837); Handly's Lesse: v. Anthony, 18 U.S. (5 Wheat.) 374 (1820).

56. See Hart \& Wechsler, The Federal Courts and The Federal System 21 (1953).

57. See Frank, Historical Bases of the Federal Judicial System, 13 Law \& Cowtemp. Prob. 3, 13-14 (1948).

58. Clark v. Allen, 331 U.S. 503 (1947); Jackson v. Harris, 43 F.2d 513 (10th Cir.1930).

59. See note 22 supra.

60. See Wragg v. Federal Land Bank, 317 U.S. 325 (1943); Chicago Bd, of Trade v. Johnson, 264 U.S. 1 (1924). Despite the fact that bankruptcy is outside the diversity jurisdiction specifically dealt with in Erie, state law may be applicable in some cares. See Hill, The Erie Doctrine in Bankruptcy, 66 HaRv. L. Rev. 1013 (1953).

61. Romero v. International Terminal Operating Co., 358 U.S. 354, 360-61 (1959): Crowell v. Benson, 285 U.S. 22 (1932).

62. Lauritzen v. Larsen, 345 U.S. 571,577 (1953).

63. Aero Mayflower Transit Co. v. Board of R.R. Comm'rs, 332 U.S. 495 (1947): AFL v. Watson, 327 U.S. 582 (1946).

64. Prudence Realization Corp. v. Geist, 316 U.S. 89 (1942); In re Pittsburgh Ry Co,. 155 F.2d 477 (3rd Cir.), cert. denied, 329 U.S. 731 (1946). 
vance at all..$^{65}$ Moreover, where the federal statute contains no explicit provision on a given point, it may nevertheless establish such a clear federal policy that state law will be ignored. ${ }^{60}$ On the other hand, Congress may by express declaration, ${ }^{67}$ or implicitly by silence, ${ }^{08}$ allow state law to govern interstitial matters in areas of federal statutory regulation.

In two areas, however, courts have created a large body of "federal law" to replace state rules of decision without adequately discussing the considerations which have led them to disregard state law. The first of these concern: cases in which a federal statute is involved, but in which a particular issue is not governed by explicit statutory provision or by clearly defined policies of the act. ${ }^{69}$ The second involves suits to which the United States is a party. In the first category of cases, the concept of the proper scope of federal decisional rules has gradually expanded. At one time only direct conflict with specific provisions or policies of the statute was held to negative the effect of state law. ${ }^{\text {io }}$ Later, however, the courts began to derive from federal acts as a

65. Here we are concerned only with the meaning and application of a statute enacted by Congress, in the exercise of its plenary power under the Constitution, to tax income. The exertion of that power is not subject to state control. It is the will of Congress which controls. . . . State law may control only when the federal taxing act, by express language or necessary implication, makes its uin operation dependent upon state law.

Burniet v. Harmel, 287 U.S. 103, 110 (1932).

66. $[\mathrm{I}] \mathrm{n}$ areas where Congress has legislated extensively so as to establish a general policy, that policy may furnish the answer to a particular question, even though the federal statutes do not expressly answer it, and though a state statute expressly enacts an contrary rule.

Fahs v. Martin, 224 F.2d 387, 392 (5th Cir. 1955); see MacGregor v. Westinghouse Elec. \& MIfg. Co., 329 U.S. 402 (1947); Sola Elec. Co. v. Jefferson Elec. Co., 317 L.S. 173 (1942).

67. The Tort Clains Act, for example, specifically makes state law applicable to determine the government's liability. 28 U.S.C. $\$ 1346$ (b) (1958).

68. See, e.g., Davies Warehouse Co. v. Bowles, 321 U.S. 144, 152 (1944); Seabreard Air Line Ry. v. Kenney, 240 U.S. 489 (1916).

69. The issue may involve the meaning of a word in the federal statute, see, s.y. De Sylva v. Ballentine, 351 U.S. 570 (1956), a matter of procedure not provided for in the act, see, e.g., Chattanooga Foundry \& Pipe Works v. City of Atlanta, silpra note 21, or the viability of state law occupying the same area, see, e.g., Sherlock v. Alling, 93 C.S. 99 (1876). Confronted with such incompletions, the court may reason that state law: applies.

But, failing a complete solution in the federal statutes (and the penumbral area where Congress has so "filled the field" that state law can have no application) we may then properly look to the foundation of legal interests and relationslips created only by state law, to which the federal statutes must be related either because by their terms they postulate such interests and relationships, or because constitutional limitations of federal power require this.

Fahs v. Martin, 224 F.2d 387, 392 (5th Cir. 1955); see Hill, State Procedural Lane in Federal Nondizersity Litigation, 69 HARv. L. Rev. 66 (1955).

70. See notes 29-31 supra and accompanying text. 
whole a policy necessitating the use of federal rather than state law to resolve interstitial matters. Thus, the Supreme Court decided in New York Cont. R.R. v. Winfield ${ }^{71}$ that the Federal Employers Liability Act provided the sole basis of recovery for those classes of employees within its coverage. Uric v. Thompson ${ }^{72}$ held that the meaning of "negligence" in the same act was to be determined by federal law, although the act itself nowhere defined the word. - The recent high-water mark in this development is Textile Workers Union v. Lincoln Mills. ${ }^{73}$ The Supreme Court there held that a statute expressly purporting to give federal courts jurisdiction over suits by or against labor unions for breach of collective bargaining agreements required the courts to formulate an entire body of substantive federal law in the field. As federal courts have come to rely upon increasingly less explicit legislative policies against using state law, ${ }^{74}$ the specific reasons for rejecting state law have tended to become both obscure and unrelated to the issue in dispute.

An example of this lack of clarity is the frequent appeal to uniformity as a reason for rejecting state decisional rules. Adoption of a uniform fecleral rule may be desirable because it achieves equality of rights and duties for both the Government and its citizens; or, it may be desirable only because governmental administration is simplified. These considerations are seldom distinguished. ${ }^{75}$ Other courts seem to use "uniformity" simply to escape state law without considering whether they are in fact achieving uniformity. For example, in O'Leary $v$. Social Security Bd., ${ }^{70}$ the court refused to apply state law, which apparently regarded cemeteries as distinct from religious corporations, in determining whether an employee of a Roman Catholic burial ground was within the Social Security Act's exclusion of religious institution employees. Instead, the court took judicial notice of Roman Catholic doctrine, which deemed cemeteries exclusively religious in purpose. The court stated that the act's "sweep is not to be interrupted by the variations and idiosyncrasies in local law." "77 The substitution of religious law for state law would involve

\author{
71. 244 U.S. 147 (1917). \\ 72. 337 U.S. 163 (1949). \\ 73. 353 U.S. 448 (1957). \\ 74. Frequently the state law is rejected even though it parallels federal law. Sec,
} e.g., Guss v. Utah Labor Relations Bd., 353 U.S. 1 (1957); Pennsylvania v. Nelson, 350 U.S. 497 (1956). Compare Southern Pac. Co. v. Jensen 244 U.S. 205 (1917).

75. See United States v. Independent School Dist., 209 F.2d 579 (10th Gir. 1954), in which the United States was allowed to recover overpayments under the federal school lunch program. The court did not distinguish between two questions, whether Oklahoma law applied to immunize a branch of the state government from stit, and whether certain procedural requirements under Oklahoma law applied to the United States. The former question permanently affects the rights of the United States, while the latter relates only to procedures required of the United States in the suits it brings.

For further discussion of "uniformity" as a reason for rejecting state law, see text accompanying notes 134-39 infra.

76. 153 F.2d 704 (3d Cir. 1946).

77. Id. at 707 . 
diverse treatment for employees of different religious groups, and probably be much harder to administer uniformly since the doctrines of other faiths are not as readily ascertainable. ${ }^{78}$ Yet neither of these factors was considered in rejecting state law.

A similar trend from state to federal law is evident in suits to which the United States is a party. ${ }^{79}$ Originally it was not thought that the presence of the United States, by itself, authorized the use of federal law. In United States $v$. Gurney, ${ }^{80}$ decided in 1808 , where the Government brought suit on an instrument, the Court followed the common law of Pennsylvania with which it said both parties were familiar when they entered into the transaction. Although disputing what Pennsylvania law was, neither party suggested that a different law should be applied. In Cox $v$. United States, ${ }^{81}$ and Duncan $v$. United States, ${ }^{82}$ in 1832 and 1833 , the Government brought suit in the Louisiana Federal Circuit Court on surety bonds issued in Louisiana covering federal officials there. Under the state's civil law rule there was a good defense, although under common law the plaintiff would prevail. The Supreme Court found the civil law rule inapplicable, not because the United States was a party, but on the theory that contracts entered into with the sovereign are to be performed at the seat of government. Thus the common law in force in the District of Columbia would govern. Recently, however, the cases of Clearfield Trust Co. v. United States ${ }^{83}$ and United States $v$. Standard Oil Co. ${ }^{8-1}$ have implied that the presence of the United States as a party frees the courts from any duty to apply state law. ${ }^{85}$

78. Democracy breeds difference of opinion and among Baptists the widest varicty of opinion is to be found. Each individual Baptist congregation is its own final court of appeal, and any individual dissident member-if he can find like-minded persons to join him-may withdraw and form a new Baptist church. Consequently: it is possible to identify only dominent traits and characteristics.

3 Encyclopedia Aasericana 220 (1956).

79. The two classes of cases are not entirely separable, for frequently both the Government as a party and an enabling statute are involved. See, e.g., United States v. Mfcabe Co., 261 F.2d 539 (Sth Cir. 1958), in which the court first held that the Commodity Credit Corporation was an instrumentality of the United States, giving rise to the issue of whether a law of North Dakota could wipe out a cause of action in favor of the United States. Id. at 543. The court then examined the federal statute involved to determine the question. Id. at 545. This left it unclear how far the status of the CCC, and how far the statute, was determinative.

80. 8 U.S. (4 Cranch.) 333 (1808). See United States v. Mforrison, 29 U.S. (4 Pet.) 123 (1830) ; United States v. Wardwell, 28 Fed. Cas. (No. 16640) (C.C.D.R.I. 1828).

81. 31 U.S. (6 Pet.) 172 (1832).

82. 32 U.S. (7 Pet) 435 (1833).

83. 318 U.S. 363 (1943).

84. 332 U.S. 301 (1947).

85. For discussion of this interpretation of Clearfield and Standard Oil, see Gorrell \& Weed, Erie Railroad: Ten Years After, 9 Onio St. L.J. 276, 291-92 (1948); Pofcher. The Choice of Law, State or Federal, in Cases Involving Government Contracts, 12 LA. L. REv. 37, 47 (1951) ; Reifenberg, Common Law-Federal, 30 ORE L. RE. 164, 172 (1951). 
In Clearfield, a WPA paycheck drawn on the Treasury of the United States was intercepted in the mails, forged, and cashed at a local store. The check was endorsed over to the Clearfield Trust Co., which in turn endorsed it over to the Federal Reserve Bank of Philadelphia, collected the amount of the check and paid to the store. The employee eventually executed an affidavit of forgery and got his salary. ${ }^{86}$ More than six months after the forgery, the United States brought suit to recover from the Clearfield Trust Company; the defendant contended that the delay of the United States in bringing suit barred its recovery. ${ }^{87}$ Under the law of Pennsylvania, applied by the District Court, ${ }^{88}$ the defense prevailed. The Court of Appeals reversed ${ }^{80}$ and was affirmed by the Supreme Court on the ground that "federal law" should govern and that under the pre-Erie federal common law delay is a defense only where it causes manifest damage to the acceptor of the forged signature. ${ }^{00}$ The Supreme Court found federal law applicable on two grounds : the disbursement of funds by the federal government is an exercise of a constitutional power, so that all rights and duties thereby created "find their roots in the same federal source"; therefore, federal courts must fashion their own law in the absence of a governing federal statute. Second, the variety of state law, if applied, "would subject the rights and duties of the United States to exceptional uncertainty."

United States v. Standard Oil Co. involved an attempt by the federal government to recover for a tort not recognized by state law. A soldier was injured in California by a Standard Oil truck and settled with the company, but the United States sued for reimbursement of the soldier's medical expenses and his salary while hospitalized. ${ }^{92}$ To allow such a recovery, the Court would have had to recognize a new cause of action in tort, analogous to one for interference with a master-servant or famiily relationship. The Government argued that the applicable law was federal common law, not the common law of California which did not recognize such torts. ${ }^{93}$ The Court agreed, reasoning that the military relationship was a creature of federal law and that every interference with that relationship should be governed by federal law. ${ }^{94}$ The need for uniformity of the Government's rights and obligations was also stressed.05 The Court's opinion interpreted Clearfield to require that state rules of decision be rejected whenever property rights of the United States are litigated, ${ }^{98}$ except where "the

86. Clearfield Trust Co. v. United States, supra note 83, at 364-66.

87. Id. at 366 .

88. The unreported opinion of the District Court for the Western District of Pem1sylvania may be found in Record, p. 13, Clearfield Trust Co. v. United States, 318 U.S. 363 (1943).

89. United States v. Clearfield Trust Co., 130 F.2d 93 (3d Cir. 1942).

90. 318 U.S. at 367,370 .

91. Id. at 367 .

92. 332 U.S. 301, 302 (1947).

93. Id. at 305 .

94. Id. at 305-06.

95. Id. at 307.

96. Id. at 306. 
Government has simply substituted itself for others as successor to rights governed by state law."97

After the decision has been made to apply federal rather than state law in a given case, the process of decision is further obscured by the failure of court: to specify the sources upon which they draw in formulating the new federal rule. ${ }^{98}$ Federal judge-made law in the traditional common-law fields may be divided into two categories. In one the court follows what it deems a sound general principle of the common law. ${ }^{99}$ For example, in United States $v$. Sabin Metal Corp., ${ }^{100}$ the court applied the general contract law dealing with unilateral mistakes in executory contracts, as set forth in Williston, The Restatement, and Corpus Juris Secundum. In the second category of cases, the federal court avowedly seeks the rule best designed to implement a federal policy ur statute, or to protect the interest of the federal government, ${ }^{102}$ without examination of or regard for common-law sources. In both $D^{\prime} \mathrm{Oench}, \mathrm{Duhme}$ if $\mathrm{Cu}$. v. FDIC ${ }^{102}$ and Dietrick v. Greaney, ${ }^{103}$ for example, the Court stated that since federal law controlled the implementation of a federal statute, inquiry into the effect of state law was unnecessary. In spite of the fact that the two categuries of federal judge-made law are quite distinct in purpose, the courts frequently write their opinions and cite their authorities without indicating whether the rule is governed by general common-law principles or dictated by particular federal interests. ${ }^{104}$

97. Id. at 309. The court found, however, that even the federal common law did not comprehend the new cause of action, and that Congress, not the courts, was the proper body to authorize the award of damages for new types of injuries. The issue concerned the fiscal policy of the United States and the determination of that policy was constitutionally within the exclusive power of Congress. Id. at 314-17. As in Clearficld, congressional silence was not taken to mean that state law should control, but rather that courts shuuld look to the general federal common law.

98. Courts sometimes still talk as though they were finding law, not making it. Ste, e.g., Kellogg Co. v. National Biscuit Co., 305 U.S. 111, 113 n.1 (1938); Whitin Mach. Works v. United States, 175 F.2d 504, 507 (1st Cir. 1949); cf. West v. American Tel. \& Tel. Co., 311 U.S. 223, 236-37 (1940). Compare Parker, Eric v. Tompkins in Retrospect: An Analysis of Its Proper Arca and Limits, 35 A.B.A.J. 19, 83-84 (1949). At other times courts face the issue squarely: "And so the concrete problem is to determine the materials out of which the judicial rule ... should be formulated." Board of Comm'rs v. United States, 308 U.S. 343, 350 (1939).

99. See, e.g., Priebe \& Sons v. United States, 332 U.S. 407 (1947); United States v. Standard Rice Co., 323 U.S. 105 (1944); United States v. Bethlehem Steel Corp., 315 U.S. 289 (1942).

100. 151 F. Supp. 683 (S.D.N.Y. 1957). Federal courts looking to the common law sometimes reject the established rule in favor of one better reasoned or more cunsistent with modern views. See, e.g., Funk v. United States, 290 U.S. 371 (1933).

101. See Note, 53 Colux. L. Rev. 991, 1002 (1953) ; cf. Comment, 40 Corswll. L.Q. 561,569 (1955) (maintaining that without specific congressional direction the courts should not give the United States any special protection).

102. 315 U.S. 447 (1942).

103. 309 U.S. 190 (1940).

104. See Clearfield Trust Co. v. United States, supra note 83, in which the Court speaks as though it were formulating the general rule, while its actual concern was probably to protect the fiscal interests of the United States. 
When federal courts decide to apply state rules of decision, they are equally reticent in articulating the standards which govern their choice. Often it is not clear whether the court must apply state law, or whether it merely chooses the state rule as an acceptable statement of federal law. ${ }^{105}$ Whether mandatory or discretionary, the basis of the court's choice is often masked in conclusionary language. They may say that it is "proper" to follow the state rule, ${ }^{100}$ or that its utilization would avoid confusion. ${ }^{107}$ They may assert that the state rule, while not "controlling," seems "suitable."108 Or they may banish queries as to the propriety of choosing state law by remarking that the federal rule on the point would be no different. ${ }^{100}$ Such reasons as these offer little guicle to future courts or litigants confronted with a variant situation.

\section{A Methodology for Rules Of Decision Problems}

Two separate problems face the federal court in search of the correct rule of decision. First, the count must decide whether the Rules of Decision Act permits it to disregard state law. If it does, the court then must formulate the federal rule.

\section{The United States as a Party}

The Clearfield-Standard Oil doctrine, rejecting state law in almost all suits to which the United States is a party, seems contrary to historical eviclence. The records and debates on the adoption of the Constitution give no indication that the United States would be subject to a body of law different from that applied to other litigants. The only reason advanced for granting federal jurisdiction over suits involving the United States was the propriety of allowing the sovereign access to its own tribunals. ${ }^{110}$ Moreover, an ex-

105. See cases cited note 7 supra.

106. United States ex rel. Hargis v. Maryland Cas. Co., 64 F. Supp. 522, 527 (S.D. Cal. 1946).

107. RFC v. Beaver County, 328 U.S. 204, 210 (1946).

108. Royal Indem. Co. v. United States, 313 U.S. 289, 297 (1941).

109. Whitin Mach. Works v. United States, 175 F.2d 504, 507 (1st Cir. 1949); United States v. Kansas City, 159 F.2d 125 (10th Cir. 1946).

110. See 2 Elliot $490 ; 3$ id. at 532. See also Tre FeDERAlist No. 80, at 588 (Hamilton ed. 1880) (Hamilton). It was pointed out that the United States still could resort to state courts. 2 Elliot 491. Fear was expressed that the grant of federal jurisdiction might become oppressive. 3 id. at 523 .

A logical argument has also been made for the proposition that Section 34 applics to suits to which the United States is a party. The Constitution grants the fecleral courts jurisdiction over cases arising under the Constitution, statutes, or treaties of the United States, and also over cases to which the United States is a party. Thus, these would seem to comprise two separate types of cases. The exception of Section 34-"except where the constitution, treaties, or statutes of the United States . . . otherwise require. . ." -refers only to the former. Cf. Romero v. International Terminal Operating Co., 358 U.S. 354 (1959) (same reasoning applied in admiralty action).

Also, more simply, if section 34 was not intended to apply to cases involving the United States, Congress could easily have said so. See Note, 53 Colus. I. Rev. 991, 994, 997 (1953). 
amination of the early cases reveals that more was required to displace state decisional rules than the fact that the United States was a party. The only two pre-Swift cases cited by the Government in its brief in Clcarficld ${ }^{111}$ to establish the principle that the United States is not to be bound by state law were Cox v. United States and Duncan v. United States, both decided upon the theory that the contracts involved were to be performed at the seat of government.112 If the Court had believed that the United States was exempt from state law, such reasoning would have been unnecessary. In view of the long-standing policy of applying state rules of decision to such cases, ${ }^{113}$ the application of "federal law" should receive more careful consideration than it has under the cases following Clearfield.

State law is probably inapposite in cases where the interest of the Government as a litigant involves execution of policy-making functions, such as exercise of the foreign relations power. But since any interest of the Government is ultimately rooted in the exercise of one of its powers, application of federal law whenever litigation affects the exercise of a governmental power would come full circle to applying federal law in every case.114 The concern for state rules of decision expressed in the Rules of Decision Act may support a distinction between active policy-making functions and less important housekeeping functions such as protection of property or payroll disbursement. ${ }^{115}$ While appli-

111. Brief for the United States, p. 11, Clearfield Trust Co. v. United States, 318 U.S. 363 (1943).

112. See notes 81-82 supra and accompanying text.

113. Admittedly, the early cases do not always say precisely that state law is being applied. In at least one case the Supreme Court clearly applied state law to a suit involving the United States. United States v. Gurney, \& U.S. (4 Cranch) 333 (1808). The tenor of other opinions suggests that the court was applying the same principles to the United States as it would to any other party. See, e.g., United States v. Barker, 25 U.S. (12 Wheat.) 559 (1827) ; United States v. Wilkins, 19 U.S. (6 Wheat) 135 (1821); Fenemore v. United States, 3 U.S. (3 Dall.) 357 (1797).

A possible explanation of the imprecision in explaining what law was being used is that, in the area of general commercial law, the law of merchants was considered uniform, and part of the law of each state, unless changed by statute. Compare Street, Is There a General Commercial Law Administered by the Courts of the United States Irrespectiz'c of the Lawes of the Particular State in Which the Court Is Held?, 21 Asr. L REc. 473, 480 (1873).

114. As one judge argued, this rationale would call for application of federal law in every case involving currency of the United States. Stone \& Webster Eng'r Corp. v. Hamilton Nat'l Bank, 199 F.2d 127, 133 (6th Cir. 1952) (dissenting opinion).

115. Clearfield Trust Co. v. United States, supro note 83 (disbursement) and Luited States v. Standard Oil Co., supra note 84 (loss of soldier's services), discussed supra notes 86-100, seem to involve governmental functions of this nature.

A distinction similar to the one suggested seems to have been employed in Denver \& R.G.R. Co. v. United States, 241 Fed. 614, 618 (1917), applying Colorado statute of limitation to tort claim of the United States.

It is established law that the government is not bound by any statute of limitations in a suit brought by it as a sovereign to enforce a public right, and the question at once arises: Is this such a suit? We think not, but rather a suit by it, as a body 
cation of state law to litigation involving the Goverment as housekeeper may afford less protection to governmental property, it need not frustrate the achievement of federal policies. For example, in both United States v. Pink ${ }^{110}$ and United States v. Curtiss Aeroplane Co., ${ }^{117}$ the United States sued as assignee of the Russian government, pursuant to the terms of the Litvinov agreement which had provided in conjunction with recognition of the Soviet Union that the United States should succeed to Soviet claims in this country. Many of these claims derived from Soviet nationalization decrees; in Pink, a suit to recover the balance of the assets of the New York branch of a Russian insurance company, the validity of such a decree was held to be a matter of federal law rather than New York conflicts rules. In Curtiss, the decisive issue was whether an agreement between Curtiss and the Provisional Russian Government not to plead the statute of limitations with respect to a previous contract was contrary to public policy. Despite the presence of the United States as a party, New York policy was held to govern, and the waiver agreement was upheld. The application of different law in each case might be explained in terms of the impact of either decision upon the foreign policy of the United States. Faced with international friction due to the Soviet government's refusal to honor American claims upon Russian corporations, the federal government had chosen to recognize the validity of the nationalization clecree and to receive assignment of nationalized assets in America as a compensatory device. ${ }^{118}$ To allow state courts to pass upon the validity of nationalization decrees would have jeopardized the entire arrangement. On the other hand, a decision concerning the ownership of one asset, a contract right, would not have prejudiced the agreement, nor would it have denied validity to a foreign government's action already affirmed by executive compact.

Interpreting the Rules of Decision Aot to allow resort to federal law only when a major federal policy is at stake may be justified by other considerations. When the Government comes into contact with private individuals in the exercise of its routine functions, the individual often may expect that state law will govern his rights and duties. The clearest case is the collection of debts owed the federal government. In satisfying its claim against one debtor, the Government may succeed to the debtor's rights against third parties who had

politic or artificial person ... to enforce a civil right. . . As an owner of property it has the same right to have it protected by local laws that other persons have. . . . Its rights and remedies in relation to its property are usually such as apply to other landowners within the state ... and it is to be treated like other persons owning lands therein and subject to local laws.

Compare United States v. Dauphin Deposit Trust Co., 50 F. Supp. 73 (M.D. Pa. 1943) (U.S. Savings Bonds; governed by Treasury regulation), with In re Smulyan, 98 F. Supp. 618 (M.D. Pa. 1951) (same; state law applied in absence of Treasury Regulations). Sce also United States v. Harpootlian, 24 F.2d 646 (2d Cir. 1928).

116. 315 U.S. 203 (1942).

117. 147 F.2d 639 (2d Cir. 1945).

118. United States v. Pink, supra note 116, at 224-25. See generally United States v. Belmont, 301 U.S. 324, 326-27, 330 (1937). 
no contemplation of dealing with the federal government. Case law has sometimes recognized the inequity of applying federal law to such transactions; for example, dicta in United States $v$. Standard Oil Co. indicates that federal law will not apply when the Government sues as the assignee of a private claim. ${ }^{13}$ On the other hand, the expectations of private parties seems to have leen ignored in holding that claims made by the United States against decedents" estates are not subject to "nonclaim" statutes which bar all claims not filed within a specified period. Administrators have been held personally liable, ${ }^{100}$ even though they may have had no way of knowing that a negotiable obliyation has passed into the Government's hands. And in the case of a tort causing damage to United States property, the Standard Oil rationale that federal property must be protected by federal law ${ }^{121}$ seems to ignore the fact that persons driving on a public highway do not expect that different rules of conduct or liabilities will ensue in the presence of Government vehicles or personnel.

The significance of the "expectation" factor follows from a consideration of the function of law in society. Law serves as far more than a set of rules for settling litigation; it establishes the rules by which men govern their affairs. ${ }^{122}$ In a sense, litigation marks the failure of the system. ${ }^{123}$ Since the law stake: out the boundaries of permissible conduct, the more certain it is, the more efficiently society should be able to function. ${ }^{124}$ To the extent that a court's choice of applicable rules of decision contradicts the expectation of the party involved, the law becomes less certain and less able to serve as a guide to conduct.

Although persons engaged in direct commercial dealings with the Initel States are put on notice that special rules of conduct may be applicable, ${ }^{12 \pi}$ use of state decisional rules may nevertheless be warranted by the fact that the ultimate responsibility for failures to perform are often determined by state law. A government contractor's nonperformance may have been caused by

119. 332 U.S. 301, 30S-09 (1947); see United States v. Hansett, 120 F.2d 121 (2.l Cir. 1941) ; United States v. Schumacher, 154 F. Supp. 425 (ED. Wis. 1957).

120. See United States v. Gibson, 101 F. Supp. 225 (D. Idaho 1951) (administratur may be personally liable to United States on claim not presented by United States within period of nonclaim statute); United States v. Deimer, 140 F. Supp. \&S (D. Wyo. 1953, (lack of notice prior to running of nonclaim statute no bar to United States chim).

121. See text accompanying note 96 sipra.

122. See Hart \& Wechsler, The Federal Courts and the Federal Systeas 634 (1953).

123. Cf. Hart \& Sacks, The Legal Process: Basic Problears in the M/aning axp Application of Law 185 (Temp. ed. 1958) (mimeographed).

124. Cf. 1 Beale, Conflict of Laws 47-48 (1935); Carter, Law: Its Origin, Growth, and Function, in Readings IN Jurisprudexce 117 (Hall ed. 1938).

125. State law does not control the rights of parties under a lease executed by the United States, Girard Trust Co. v. United States, 149 F.2d 872 (3rd Gir. 1945), or under contracts of employment between federal corporations and individuals, United States .. Goodwin, 66 F. Supp. 214 (D. Neb. 1946), or under policies of the National Life Insurance Company, Woodward v. United States, 167 F.2d 774 (8th Cir. 1948), or under eontracts 
the conduot of his subcontractors, from whom he will seek recovery. If different rules of decision are applied in the two actions ${ }^{120}$-for example, if the subcontractor can assert a state law defense not open to the general contractor under federal law-the responsibility for losses may be inequitably placed. A similar problem would arise when the government sues a prior holder of a negotiable instrument, ${ }^{12 \tau}$ or one of several joint tortfeasors. Absent statutory provisions requiring federal law to be applied in the Government's action, use of state law in the first instance seems more likely to effect an equitable solution to the controversy.

\section{Cases Involving Interpretation of a Federal Statute}

Choosing the correct rule of decision to be applied in cases involving a federal statute presents somewhat different considerations. State rules of clecision might be applied in any of three ways: (1) a term of the act may require further definition; (2) no provision may be made for certain matters, such als a statute of limitations or survival of actions: (3) the statute may regulate certain areas without indicating whether existing state law in that arca is preempted or continues in force where the federal law does not specifically govern. ${ }^{128}$ In the absence of evidence of congressional intent to the contrary, state law would seem applicable under the Rules of Decision Act in all three cases, for the statute does not "otherwise require or provide." Of course. courts examining the major purposes of the act may find that the application of state law will cause results contrary to the objectives sought by Congress. ${ }^{140}$ In some cases, the lack of uniformity itself may obstruct the operation of a statute even though none of the various results are by themselves objectionable. ${ }^{130}$ But this is, in effect, simply a finding of congressional intent not to be bound by state law. Without that finding, state law should be followed.

of sale with the government, United States v. Sabin Metal Corp., 151 F. Supp. (\$3 (S.D.N.Y. 1957).

On the other hand, rights of subcontractors who do not deal direotly with the govern. ment have been governed by state law. See Blair v. United States ex. ral. Gregory-Hogath, 147 F.2d 840 (8th Cir.), modified for other reasons, 150 F.2d 676 (8th Cir. 1945); United States ex rel. Gillioz v. John Kerns Constr. Co., 50 F. Supp. 692 (E.D. Ark. 1943), revid on other grounds, 140 F.2d 792 (8th Cir. 1944); United States ex rel. Wilkinson v. Liange, 35 F. Supp. 17 (D. Md. 1940), aff'd, 120 F.2d 886 (4th Cir. 1941).

126. Under the Miller Act, 49 Stat. 793 (1935), 40 U.S.C. $\$ \$ 270$ (a)-(d) (1958), actions between the United States and prime contractors have been held to be governed by federal law. R. P. Farnsworth \& Co. v. Electrical Supply Co., 112 F.2d 150 (5th Cir. 1940). Suits by the contractor against his subcontractor, however, seem to follow principles of state law. See note 125 supro.

127. See Fulton Nat'l Bank v. United States, 197 F.2d 763 (5th Cir. 1952) (dissenting opinion, Rives, J.), a situation much like Clearfield. But here it seems that the defendant was barred by state law from recovery against prior endorsers.

128. See note 69 stipra.

129. See, e.g., notes 67-68 supra and accompanying text.

130. See, e.g., T. \& M. Transp. Co. v. S. W. Shattuck Chem. Co., 158 F.2d 909 (10th Cir. 1947) (semble) ; Federal Sav. \& Loan Ins. Corp. v. Kearney Trust Co., 151 F.2d 
One of the attitudes leading to the rejection of state law in this area seems to be a presumption that Congress must have intended all issues arising in the construction of a federal statute to be governed by federal law. In Schucabacher $v$. United States, ${ }^{131}$ where dissident shareholders opposed a railroad merger because the plan allegedly violated their charter rights under state law, the Supreme Court held that charter rights of such stockholders werc within the purview of the Transportation Act of 1940 even though the act itself did not mention the problem. The Court then considered whether, in determining charter rights, the ICC should look to state law or should fashion its rules from the act's general criteria. The majority reasoned that federal law must apply because "the Commission likely would not and probably could not be given plenary and exclusive jurisdiction to interpret and apply any state's law."132 While the Court also supported its decision by finding that state law was inconsistent with the policies of the Transportation Act, the first reason given would completely preclude the use of state law for filling in the interstices of federal legislation. ${ }^{133}$ Wholesale rejection of state law, when the federal act does not so require, seems inconsistent with the policy expressed in the Rules of Decision Act.

When federal law is chosen for the purpose of uniformity, several distinct considerations under the heading of "uniformity" are seldom distinguished. If the application of a different rule in every state will produce different rights and duties under the act, uniformity becomes a powerful argument. ${ }^{134}$ Even here, however, the federal government may have intended to create a certain interest and to aliow states to administer that interest according to local policies. In a statute providing for renewal of copyrights, for example, Congress provided that the right to renew should pass to the widow and children and then to executors and heirs of the original holder, apparently contemplating that each state should distribute the interest according to its own laws of descent and distribution. ${ }^{135}$ In some circumstances, moreover, the variety of state laws

720, 725 (8th Cir. 1945); Matcovich v. Anglim, 134 F.2d 834 (9th Cir.), cert. deniid, 320 U.S. 744 (1943).

131. 334 U.S. 182 (1948).

132. Id. at 198.

133. Similar results are suggested by the reasoning of Bowles v. Farnuers Aat'l Banh, 147 F.2d 425, 430 (6th Cir. 1945), in which the court held that a state survival of accius statute could not apply because the instant action had been created by federal statute. See also Morgan v. Commissioner, 309 U.S. 78, 81 (1940); Bishop v. Rosin, 69 F. Supy. 915 (E.D. Mich. 1946).

134. See De Sylva v. Ballentine, 351 U.S. 570, 583 (1956) (concurring opinion, Douglas, J.); Royal Indem. Co. v. United States, 313 U.S. 289, 297 (1941) (dissenting opinion, Black, J.).

Even if a general rule of common law is adopted by the federal courts, uniformity may not immediately obtain. Since circuit courts are not bound by each other's decision. see 1 MIOORE, FEDERAL PRACTICE \0.402[1] (1959), conflict among the circuits can limit the benefits of "uniformity." See, e.g., Note, 69 Y ALE L.J. 309, $316 \&$ n.44 (1959). And it.is by no means certain that the Supreme Court will grant review. See Stern, Dcrial of Certiorari Despite a Conflict, 66 HARv. L. REv. 465 (1953).

135. De Sylva v. Ballentine, 351 U.S. 570 (1956). 
may merely impose a procedural or administrative burden on the federal government without affecting its ability to treat citizens equally. For example, while state laws dealing with assention of claims against decedents' estates may require the Government to adopt different methods of operntion in each state, they do not affect the power to achieve the same uniform results. ${ }^{130}$ Balanced against the state's interest in dealing with such matters uniformly, the rewards of national uniformity in this case may be of less weight. For that reason, the actual administrative burden caused by the application of diverse state laws should be assessed in each case. State laws on the matter may not in fact differ very widely. ${ }^{137}$ Even if they do, it remains to be asked whether application of the law state-by-state will create the anticipated confusion. For example, in Otis \& Co. v. $S E C,{ }^{138}$ charter provisions under state law providing for specified preferences upon liquidation were held inoperative in a simplification by liquidation under the Public Utility Holding Company Act. Here the SEC's power to formulate "fair and equitable" plans for liquidation would be hampered by enforced compliance with all the varying state laws. But the effect of variation may be neutralized by customarily handling the matter at the local level through officials familiar with state law, as is the case with the Veterans Administration. ${ }^{139}$ In this case, no major administrative problems are presented by the use of state law.

When the Rules of Decision Act compels acceptance of state decisional law due to the absence of any conflict with the federal statute, the court's decision cannot be made with the same certainty that obtains when Congress specifically adopts the state rule of decision. In the former situation, the court must provide for circumstances in which an unforeseen state rule of decision will produce a result contrary to one of the purposes of the statute. Thus, in interpreting the federal statute allowing the renewal of a copyright by the children of the copyright holder, the Supreme Court held that state rules of decision would define the term "children," except where the state law was abnormal. ${ }^{140}$

136. It is generally held that the United States is not bound by state nonclaim statutcs. See United States v. Summerlin, 310 U.S. 414 (1940); United States v. Deimer, 140 F. Supp. 88 (D. Wyo. 1953) ; United States v. Anderson, 66 F. Supp. 870 (D. Minn. 1946). If such statutes were held applicable, the United States would not be deprived of a right, but would merely be forced to bring its actions more within the time allowed by each state. In many jurisdictions where the state itself cannot recover a claim brought beyond the period of the nonclaim statute, see Hill v. State, 23 Ark. 604 (1861); In rc Peers' Estate, 234 Iowa 403, 12 N.W.2d 894 (1944); Donnally v. Montgomery County' Welfare Bd., 200 Mdd. 534, 92 A.2d 354 (1952); State v. Evans, 143 Wash. 449, 255 Pac. 1035 (1927), the United States seems entitled to no greater consideration.

137. See Shulman, The Demise of Swift v. Tyson, 47 Y YLE L.J. 1336, 1349 (1938).

138. 323 U.S. 624 (1945).

139. See Mishkin, The Variousness of "Federal Law": Competence and Discrction in the Choice of National and State Rules for Decision, 105 U. PA. L. REv. 797, 818-19 (1957).

140. De Sylva v. Ballentine, 351 U.S. 570, 581 (1956) ; accord, Nebraska v. United States, 164 F.2d 866, 868 (8th Cir. 1947) (unusual property concept held an exception 
Courts sometimes assert that they are not bound to apply state law by the Rules of Decision Act, but nevertheless choose to apply the law of each state as a matter of discretion. The Supreme Court has held, for example, that interest rates due on defaulted contracts with the Government must be a matter of federal law, but that the rate in force in the state where the contract was executed and performed would be incorporated as the federal rule, because no federal statute or policy would be offended by the use of individual state rules. ${ }^{141}$ Similarly, state interest rates have been applied in federal condennation proceedings as a matter of discretion when the relevant federal statute was construed to give federal courts power to formulate their own rule. ${ }^{142}$ Phrasing the result in terms of discretion rather than compulsion does not change the substantive rule applicable in the particular case. Mforeover, the reasons for choosing state law seem to be the same-in both cases, decisions rely on the absence of a conflicting federal policy. The major significance of the "discretion" terminology seems to be an assertion by the court that it will remain free to examine each state law that comes before it and to reject any which it finds incompatible with some federal policy. ${ }^{143}$ Since a decision to apply state law under the Rules of Decision Act, other than that following clear congressional directive to apply state law, must be qualified in the same way, arguably the distinction between mandatory and discretionary application of state law is nonexistent in this context. The Rules of Decision Act cannot result in rigid, mandatory rules any more than the court's discretion is really freed by the absence of specific congressional policy on a given issue.

Since the process of defining the unarticulated objectives of federal legislation is admittedly imprecise and often a matter of guesswork, ${ }^{144}$ a court choosing rules of decision in this area should also give weight to some of the subsidiary considerations previously mentioned. For example, the court could consider whether the statute deals with areas of commercial relations in which private parties may reasonably have expected state law to govern, and whether imposition of a federal rule may not subject different parts of the same transaction to different laws. The court may consider also the impact of a federal rule of decision upon related state policies and governmental operations. Courts have occasionally supported the choice to apply state law by mentioning these factors under the heading: "Congress must have intended." Thus, in RFC : Beaver County", the meaning of "real property" in the Reconstruction Finance

to general rule that state law governs real property rights); Puhfahl v. Estate of Parlis, 299 U.S. 217 (1936) (court will consider whether state law discriminates against the federal government).

141. Royal Indem. Co. v. United States, 313 U.S. 289, 297 (1941).

142. Brown v. United States, 263 U.S. 78, 87 (1923); see Seaboard Airline Ry. v. United States, 261 U.S. 299, 306 (1923).

143. See Mishkin, stpra note 139 , at 804-05.

144. See Textile Workers Union v. Lincoln Mills, 353 U.S. 448, 452, 455 (1957); id. at 462 (Frankfurter, J., dissenting) ; Burnet v. Guggenheim, 28S U.S. 280, 288 (1933): Bickel \& Wellington, Legislative Purpose and the Judicial Process: The Lincoln Mills Case, 71 Harv. L. Rev. 1, 14-17 (1958). 
Corporation Act was left to be determined by state law. The act provided that the real property of the RFC was to be subject to state and local taxation, and the Court emphasized the confusion which would result if the local taxing authorities could not employ their accustomed standards. ${ }^{145}$ Similar results should obtain where the state has primary responsibility for the field of law in question-e.g., real property, ${ }^{146}$ family relations, ${ }^{147}$ or estates ${ }^{148}$-while areas of exclusively federal interest such as income taxation ${ }^{140}$ or foreign relations ${ }^{150}$ will be best served by a federal rule.

\section{Formulating A Federal Rule}

When it is determined in a given instance that state decisional rules are not binding, the federal court remains faced with the problem of formulating a substantive federal rule. While there may be a federal common-law doctrine which would furnish a convenient rule, the process of choosing a federal rule of decision requires more than the mere replacement of one rule with another ready made. If the federal rule is to satisfy the objection made to state rules of decision. its formulation must be governed by those same considerations which counseled rejection of the state law. ${ }^{\mathbf{1 5 1}}$ Thus the federal law applied to Soviet nationalization decrees under the Litvinov agreement must look to that agreement and seek to effectuate it. ${ }^{152}$ Similarly, if state law is rejected becatise it lacks uniformity, the court should not adopt equally varied church laws in its place..$^{10: 3}$

Some courts have been influenced in their choice of decisional rules by the alternative sources of law available. For example, if the issue before the court deals with family law, the court may feel bound to look to state law because there is no federal common law of domestic relations. ${ }^{164}$ Reluctance to creatr

145. 328 U.S. 204, 210 (1946) ; see Davies Warehouse Co. v. Bowles, 321 U.S. 144 (1944) (definition of "public utility"). But see Board of Comm'rs v. United States, 30: U.S. 343 (1939), discussed in text accompanying note 40 supra.

146. See Hines Yellow Pine Trustees v. Martin, 268 U.S. 458, 462 (1925); Clarke v. Clarke, 178 U.S. 186 (1900); Lowndes v. Huntington, 153 U.S. 1 (1894); Halsted v. Buster, 140 U.S. 273 (1891).

147. See Ohio ex rel. Popovici v. Agler, 280 U.S. 379 (1930); In re Burrus, 136 U.S. 586 (1890) ; Meister v. Moore, 96 U.S. 76 (1878); Payne v. Commissioner, 141 F.2d 398 (5th Cir. 1944); Wilson v. Wilson, 128 F. Supp. 88 (D. Mass. 1955); Kowalski v. Chicago Great W. Ry., 84 Fed. 586 (N.D. Iowa 1898), aff'd, 92 Fed. 310 (8th Cir. 1899).

148. See Lyeth v. Hoey, 305 U.S. 188 (1938); De Vaughn v. Hutchinson, 165 U.S. 566 (1897) ; Roberts v. Lewis, 153 U.S. 367 (1894); United States v. Fox, 9.1 U.S. 315 (1876); Sharpe v. Commissioner, 107 F.2d 13 (3d Cir. 1939); Wells v. Brown, 255 Fed. 852 (8th Cir. 1919).

149. See note 65 supra.

150. See, e.g., Perez v. Brownell, 356 U.S. 44 (1958).

151. See text accompanying notes $48-68$ supra.

152. See text accompanying notes $116-18$ supra.

153. See text accompanying notes 76-78 supra.

154. De Sylva v. Ballentine, 351 U.S. $570,580-81$ (1956) ("there is no federal law of domestic relations"), 42 A.B.A.J. 762, 31 N.Y.U.L. Rev. 1319. See also RFC v. Beaver County, 328 U.S. 204, 208-10 (1946) ; Board of Directors v. RFC, 170 F.2d 430, 432 (8th 
wholly new doctrines is a trait common to any court dealing with judge-made law, and is a valid consideration in this case. An attempt to write new federal law without antecedents is fraught with uncertainty and potential unfairness. ${ }^{135}$ On the other hand, the absence of an existing federal law ought not to assume so much importance that the court feels compelled to follow state law. ${ }^{150}$ The decision to apply federal law does not depend upon the presence of a ready made federal law; it means only that certain considerations have led the court not to be bound by a state's common law. If no state's law will satisfy those objections, the court must of necessity fashion a federal law which will.157

When looking to the reasons for which state decisional rules were inapplicable, courts should distinguish between reasons of substance and reasons of form. When only uniformity is sought in a suit to which the United States is a party, for example, considerations of how best to promote the interest of the Government seem improper. ${ }^{158}$ The court's primary concern should be to discover the rule of state or federal common law which it would find preferable if the controversy involved two private parties, giving weight to the intrinsic merits of the rule and its familiarity to the parties affected. The need for impartial rules in this area has sometimes been recognized by courts which state that the Government, litigating matters arising from its commercial ventures, must "do business on business terms."159

Cir. 1948); Ferguson v. Union Nat'l Bank, 126 F.2d 753, 759 (4th Cir. 1942); In re United Pub. Util. Corp., 52 F. Supp. 975, 976-77 (D. Del. 1943); In re Jacksonville Gas. Co., 46 F. Supp. 852, 858 (S.D. Fla 1942).

155. See Mahnich v. Southern S.S. Co., 321 U.S. 96, 112-13 (1944) (dissenting opinion, Roberts, J.) ; Jackson, Decisional Lawu and Stare Decisis, 30 A.B.A.J. 334 (1944).

156. See note 98 supra.

157. See, e.g., Board of Comm'rs v. United States, stpra note 145 , at $\mathbf{3 5 0 .}$

158. It may be pointed out that in the usual case in which local law is held inapplicable to a federal suit, it is the United States as plaintiff which profits by the denial of a defense under local law. ... But the principle of the application of federal law is not in the least affected thereby. What is sauce for the federal plaintiff as gander ought to be sauce for it when it is goose.

United States v. Matthews, 139 F. Supp. 683, 690 (N.D. Cal. 1956).

[A] government may suffer loss through negligence of its officers. If it comes down from its position of sovereignty, and enters the domain of commerce, it submits itself to the same laws that govern individuals there.

Cooke v. United States, 91 U.S. 389, 398 (1875).

Nevertheless, the courts sometimes seem to manipulate the concepts of state and federal law to benefit the government. See, e.g., Fulton Nat'l Bank v. United States, 197 F.2d 763 (5th $\mathrm{Cir}$. 1952) (Georgia law relied on to establish that endorsements of government checks were illegal or unauthorized; federal law applied to obviate Georgia statute barring recovery on forged endorsements after one year) ; $c f$. Rhode Island Discount Co. $v$. United States, 118 Ct. Cl. 262, 94 F. Supp. 669 (1951).

159. United States v. National Exchange Bank, 270 U.S. 527, 534 (1926) ; accord, Cooke v. United States, 91 U.S. 389 (1875). But cf. United States v. MfcCabe Co., 201 F.2d 539, 543-44 (8th Cir. 1958), suggesting that a different law applied to the CCC as a government corporation than would have applied had it remained a Delaware corporation. 
Almost as important as the process of decision itself is the manner in which such decisions are articulated. Federal law does not replace state law simply because the United States is a litigant, or because a federal statute is somehow involved. State law must be found unsuitable for certain specific reasons. Unless those reasons are made clear, courts in subsequent cases may be misled into rejecting state law when, despite similarity of issues, the real reasons for the earlier decision are not present. ${ }^{160}$ And since the substance of the federal rule itself will depend upon the reasons for rejecting state law, courts cannot intelligently create a "federal law" unless such reasons are known and expressed. When the federal rule is chosen, careful enunciation of the source from which the rule was drawn ${ }^{161}$ is necessary to avoid misapplication of that precedent in other cases. For example, a clear understanding that the federal law is based upon some statutory policy rather than common law will obviate consideration of any common law defenses. ${ }^{162}$ The need to articulate all the considerations whioh influence the choice of decisional rules becomes manifest when the process of decision is recognized for what it is : the jucliciary is making federal law, not finding it.

160. A recent example of this uncertainty is United States v. McCabe Co., 261 F.2d 539 (8th Cir. 1959), reversing United States v. McDonald Grain \& Seed Co., 154 F. Supp. 329 (D.N. Dak. 1957). Both the District Court and the Court of Appeals used the samic passage from RFC v. Breeding, 211 F.2d 385 (10th Cir. 1954), to support their holdings and reached precisely contrary conclusions, 261 F.2d at 543; 154 F. Supp. at 334.

161. See notes 48-52 supra and accompanying text.

162. Thus state law, which apparently would have dictated a contrary result, was not considered in United States v. View Crest Garden Apartments, Inc., 268 F.2d 380 (9th Cir. 1959) (action to foreclose FHA montgage and appoint receiver); United States $v$. Starks, 239 F.2d 544 (7th Cir. 1956) (construing clause of lease of United States military reservation).

The source of federal law seems to have been misapprehended in Priebe \& Sons $v$. United States, 332 U.S. 407 (1947). The Court applied a common law presumption against liquidated damage clauses in a suit involving war contracts, although the basis of federal law seems to have been the necessity of effectuating the emergency war powers of the federal government. 